\title{
REFLETINDO SOBRE A PROVINHA BRASIL A PARTIR DAS DIMENSÕES SOCIOCULTURAL, LINGUÍSTICA E COGNITIVA DA LEITURA
}

\section{Carla CRISTOFOLINI*}

- RESUMO: Este artigo propõe-se a interpretar como a leitura, em suas dimensões sociocultural, linguística e cognitiva (CERUTTI-RIZZATTI, 2009), está contemplada na avaliação nacional padronizada da alfabetização, a Provinha Brasil, em sua primeira edição do ano de 2009. Para tanto, são traçadas algumas reflexões a partir de documentos norteadores da ação pedagógica tanto federais (BRASIL, 2007) quanto municipais (SECRETARIA MUNICIPAL DE EDUCAÇÃO, 2000, 2007), dos Guias que acompanham o kit da Provinha e dos resultados obtidos nessa avaliação por cinco turmas de $2^{\circ}$ ano de uma escola pública, municipal, da grande Florianópolis. As questões da Provinha foram classificadas em dois grandes grupos (questões focadas nas habilidades de decodificação e aquelas envolvendo textualização) e são discutidas individualmente, aliando discussão teórica (conceitos pertinentes à alfabetização e letramento) com os resultados apresentados pelos alunos. Como principal conclusão, observa-se que essa edição da Provinha Brasil foca principalmente as dimensões linguística e cognitiva da leitura, em detrimento da dimensão sociocultural.

- PALAVRAS-CHAVE: Leitura. Alfabetização. Letramento. Provinha Brasil.

\section{Introdução}

A Provinha Brasil é uma avaliação diagnóstica, apresentada em um instrumento padronizado, que tem por objetivo auxiliar as escolas a fazer uma análise do trabalho em relação à alfabetização e ao letramento. Teve sua primeira edição nacional em 2008 e, a partir de 2009, corresponde a duas avaliações anuais (uma no início e outra no final do ano letivo). No ano de 2009, a primeira avaliação, aqui discutida, foi aplicada em meados de abril. Pretendemos, então, discutir algumas questões pertinentes a esse processo. ${ }^{1}$

Colocamo-nos como pesquisadores participantes, pois estivemos envolvidos, por fins profissionais, nessa avaliação em uma escola pública da grande Florianópolis. Participamos de todo o processo, desde as primeiras instruções

* UFSC - Universidade Federal de Santa Catarina. Florianópolis - SC - Brasil. 88040-970 - carlaufsc@uol.com.br.

1 Este artigo foi desenvolvido durante a disciplina "Ensino da Leitura", no programa de Pós Graduação em Linguística da Universidade Federal de Santa Catarina, sob orientação da Professora Doutora Mary Elizabeth Cerutti-Rizzatti. 
advindas da Secretaria Municipal de Educação (doravante SME) até a tabulação, interpretação e discussão dos dados junto à equipe escolar. Inclusive, estivemos presentes em todas as salas de aula durante a aplicação da Provinha propriamente dita, o que nos credencia a incluir observações pessoais às discussões.

Quanto às posições teóricas, adotamos as concepções de Cerutti-Rizzatti (2009b, p.02), quando diz que "a proficiência em leitura não pode mais ser vista como um conjunto de habilidades monolíticas que o ser humano desenvolve em sua internalidade cognitiva" e que é fundamental entender o ato de leitura a partir de três dimensões - sociocultural, linguística e cognitiva. Achamos necessário, antes de analisar e discutir os resultados apresentados pelos alunos na primeira avaliação da Provinha Brasil, apresentar e entender alguns aspectos das três dimensões da leitura, para que possamos, depois, refletir sobre cada um delas no ato da leitura, mais especificamente, o exigido pela Provinha Brasil.

Concordamos com as posições de Soares (2003), quando defende que a apropriação da leitura e da escrita se faz por duas vias: o aprendizado da técnica (relacionar fonemas com grafemas, segurar um lápis, compreender a direção e orientação da escrita, entre outras habilidades) e o desenvolvimento de práticas de uso dessa técnica, ${ }^{2}$ pois acreditamos que ela contempla as três dimensões da leitura defendidas neste artigo.

Assim, apresentamos a visão norteadora de alfabetização no Ensino Fundamental de nove anos dada pelos vários documentos do Ministério de Educação e Cultura (doravante $\mathrm{MEC}$ ), principalmente em relação à leitura e à Provinha Brasil, instrumento de avaliação padronizado nacionalmente, sobre a qual o ato de leitura, em suas três dimensões, será analisado; apresentamos também as orientações da respectiva SME do município a respeito da alfabetização, bem como a população avaliada pela Provinha Brasil, em nosso caso, as cinco turmas de $2^{\circ}$ ano que responderam a Provinha Brasil e seus respectivos indicadores (resultados).

\section{Provinha Brasil: uma discussão sobre orientações dos documentos oficiais para alfabetização}

Um dos documentos norteadores de nossas discussões é o Pró-Letramento (BRASIL, 2007), programa do MEC para formação de professores alfabetizadores, por entendermos ser um documento oficial convergente com a posição teórica adotada pela Provinha Brasil (sendo inclusive citado como referência para

\footnotetext{
Processos que a autora chama de alfabetização e letramento, respectivamente. Voltaremos a essa discussão muito brevemente, pois concordamos que são fundamentais e indispensáveis para a apropriação da escrita, independentemente da forma como sejam nomeados.
} 
a elaboração dessa mesma prova) e por ser um documento de fácil acesso aos professores, disponível e discutido na escola da rede a que esta análise corresponde. Nesse material, encontramos a definição de leitura:

[...] uma atividade que depende de processamento individual, mas se insere num contexto social e envolve disposições atitudinais, capacidades relativas à decifração do código escrito e capacidades relativas à compreensão, à produção de sentido. A abordagem dada à leitura, aqui, abrange, portanto, desde capacidades necessárias ao processo de alfabetização até aquelas que habilitam o aluno à participação ativa nas práticas sociais letradas, ou seja, aquelas que contribuem para o letramento. (BRASIL, 2007, p.39).

Retomando as dimensões da leitura propostas por Cerutti-Rizatti (2009a, 2009b), observamos, na definição acima, a abrangência das três dimensões da leitura: contempla a dimensão sociocultural, pois insere a leitura em um contexto social; compreende as dimensões linguística e cognitiva, uma vez que a leitura é permeada pela decifração do código escrito e pelas capacidades relativas à compreensão e à produção de sentido, habilidades que dependem tanto de questões como acesso ao código e relativas à materialidade do texto (dimensão linguística), quanto de compreensão leitora (dimensão cognitiva).

Nos documentos municipais norteadores da prática pedagógica na rede municipal analisada (SÃO JOSÉ, 2000, 2007), encontramos:

\begin{abstract}
Alfabetizar é oportunizar às crianças o uso da língua materna em contextos significativos, pressupondo a apropriação de diferentes linguagens (da oral, da escrita, da matemática, das ciências naturais e sociais das artes, do corpo), e o aprendizado de diferentes conhecimentos, na relação que estabelecem entre si, com o professor e sua intencionalidade e com a linguagem escrita em suas diferentes manifestações. (SÃO JOSÉ, 2007, p.6).
\end{abstract}

Observamos, na visão adotada pela Secretaria Municipal de Educação, uma concepção mais ampla de alfabetização, que não contempla diretamente o que Soares (2003) chama de "técnica da alfabetização", as especificidades do processo de apropriação da língua escrita. Essa posição é defendida também nas orientações ao professor alfabetizador em relação à alfabetização a qual é considerada "um processo de constituição dos sentidos", em que as experiências vividas, a interação, a medição, a dialogicidade são fundamentais, e a linguagem é um fator primordial na elaboração do conhecimento. Nessa proposta, " [...] a criança é considerada um sujeito histórico que se apropria do conhecimento a partir da relação entre as experiências vividas, da interação e da mediação, num processo simultâneo de desenvolvimento e aprendizagem." (SÃO JOSÉ, 2007, p.6). 
Quando voltamos aos documentos do MEC, observamos também a distinção entre os conceitos de alfabetização "[...] processo específico e indispensável de apropriação do sistema de escrita, a conquista dos princípios alfabético e ortográfico que possibilita ao aluno ler e escrever com autonomia [...]" (BRASIL, 2007, p.12) e letramento "processo de inserção e participação na cultura escrita", porém, como dois conceitos imbricados, não excludentes, tampouco autossuficientes.

Essa proposta considera que a alfabetização e o letramento são processos diferentes, cada um com suas especificidades, mas complementares e inseparáveis, ambos indispensáveis. Assim, não se trata de escolher entre alfabetizar ou letrar; trata-se de alfabetizar letrando. Também não se trata de pensar os dois processos como sequenciais, como se o letramento fosse uma espécie de preparação para a alfabetização, ou então, como se a alfabetização fosse condição indispensável para o início do processo de letramento. O desafio que se coloca para os primeiros anos da educação fundamental é o de conciliar esses dois processos, assegurando aos alunos a apropriação do sistema alfabético-ortográfico e condições possibilitadoras do uso da língua nas práticas sociais de leitura e escrita. (BRASIL, 2007, p.13).

Nas distinções entre a visão de alfabetização nos documentos de âmbito federal e municipal, observamos que ambas contemplam a dimensão cultural do ato de ler, a preocupação que a alfabetização não seja somente uma habilidade sem sentido; porém não podemos perder de vista as dimensões cognitiva e linguística, fundamentais ao processo de alfabetização, observadas mais claramente nos documentos federais. Ainda nessas distinções, uma outra preocupação dos documentos federais é a distinção entre os conceitos de alfabetização e letramento, o que não é observado nos documentos municipais.

Abrimos aqui um parêntese para discutir, brevemente, algumas implicações da "simplificação" desses conceitos. Embora o documento oficial distinga a apropriação de leitura e escrita em processos de alfabetização e de letramento, preconiza, ao mesmo tempo, que sejam indissociados. Até entendemos que essa possa ser uma "divisão pedagógica" a fim de se assegurar a compreensão desses dois aspectos; contudo assumir tal posição, a nosso ver, significa correr o risco da partição dos conteúdos. Street (2003) apresenta a premissa que o letramento não deve ser tomado apenas como produto técnico e neutro (modelo autônomo de letramento), mas sim como uma prática social concreta, vinculada ao contexto social dos indivíduos, o qual é significativo na forma por meio da qual eles lidam com a escrita. Em outras palavras, a dimensão cognitiva da apropriação da escrita deve ser entendida em relação às estruturas culturais de poder que os contextos dessa apropriação apresentam na escola (KLEIMAN, 1995). Assim, talvez, um possível caminho para evitar esta "partição" seria adotar 
a posição defendida por Cerutti-Rizzatti (2009b): o letramento como continente, tendo a alfabetização como um de seus conteúdos, ou seja, ver o letramento como um fenômeno amplo relativo ao processo de apropriação e uso da escrita - modalidade concebida em suas implicações antropológicas e sociológicas - tendo a alfabetização como um de seus desdobramentos fundamentais no que diz respeito à escolarização. Sob essa perspectiva, letramento seria continente e alfabetização um de seus conteúdos. Assim, a expressão "alfabetizar letrando" adotada pelos documentos oficiais pode gerar a noção simplificada de alfabetização como restrita aos processos de decodificação da língua escrita, quando, na verdade,

[...] a alfabetização seria concebida como uma das múltiplas formas que assume a dinamicidade do processo de letramento, tendo a sua especificidade: instrução formal, sistemática, que foca na natureza linguístico-sistêmica da língua escrita tanto quanto em sua natureza funcional. Aceitar isso requer compreender a alfabetização como um conceito legítimo que implica o domínio do sistema alfabético para usar a escrita na sociedade, não podendo circunscrever-se a questões formais apenas. (CERUTTI-RIZZATTI, 2009b, p.2).

Fizemos tal discussão, pois entendemos que essa não é somente uma distinção de termos ou conceitos, mas é a base das orientações dadas aos professores e, consequentemente, da atividade efetiva com a apropriação de leitura e escrita em sala de aula.

Voltando aos documentos oficiais, encontramos, nos dois documentos norteadores (o federal e o municipal), habilidades referentes à leitura, ${ }^{3}$ em ambas as esferas administrativas apresentadas por meio de quadros. Primeiramente apresentamos os dois quadros referentes à apropriação do sistema de escrita e de leitura do Pró-Letramento ${ }^{4}$ e, em seguida, os dois quadros elaborados pela SME:

3 Não só à leitura, mas também às demais habilidades envolvidas no processo de alfabetização. Porém, como o objetivo deste artigo é discutir leitura, somente estes quadros serão apresentados e discutidos. São, no total, 5: Compreensão e valorização da cultura escrita, Apropriação do sistema de escrita, Leitura, Produção e Desenvolvimento da oralidade

4 Nestes quadros, cada habilidade tem a sua gradação especificada para cada série escolar. Assim, a sigla I significa Introduzir; T, Trabalhar sistematicamente; C, Consolidar e R, Retomar. Quanto às três letras, aparecem conjuntamente, a habilidade deve ser dominada mais cedo e deverá ser introduzida, trabalhada e consolidada na mesma série escolar. Há ainda a gradação de cores: o tom mais claro simboliza que a capacidade deve ser introduzida ou retomada; o tom médio, que deve ser trabalhada de maneira sistemática; o tom escuro representa a consolidação da habilidade. 
Quadro 1 - Apropriação do sistema de escrita: conhecimentos e capacidades

\begin{tabular}{|c|c|c|c|}
\hline \multicolumn{4}{|c|}{ Apropriação do sistema de escrita: conhecimentos, capacidades e atitudes } \\
\hline CAPACIDADES, CONHECIMENTOS E ATITUDES & $1^{\circ}$ ano & $2^{\circ}$ ano & $3^{\circ}$ ano \\
\hline $\begin{array}{l}\text { Compreender diferenças entre a escrita alfabética e outras } \\
\text { formas gráficas }\end{array}$ & $\mathrm{I} / \mathrm{T} / \mathrm{C}$ & $\mathrm{R}$ & $\mathrm{R}$ \\
\hline Dominar convenções gráficas: & $\mathrm{I} / \mathrm{T} / \mathrm{C}$ & $\mathrm{R}$ & $\mathrm{R}$ \\
\hline $\begin{array}{l}\text { (i) compreender a orientação e o alinhamento da escrita da } \\
\text { língua portuguesa }\end{array}$ & $\mathrm{I} / \mathrm{T} / \mathrm{C}$ & $\mathrm{R}$ & $\mathrm{R}$ \\
\hline $\begin{array}{l}\text { (ii) compreender a função de segmentação dos espaços em } \\
\text { branco e da pontuação de final de frase }\end{array}$ & $\mathrm{I} / \mathrm{T} / \mathrm{C}$ & $\mathrm{R}$ & $\mathrm{R}$ \\
\hline $\begin{array}{l}\text { Reconhecer unidades fonológicas como sílabas, rimas, } \\
\text { terminações de palavras, etc. }\end{array}$ & $\mathrm{I} / \mathrm{T} / \mathrm{C}$ & $\mathrm{T}$ & $\mathrm{R}$ \\
\hline Conhecer o alfabeto & $\mathrm{I} / \mathrm{T}$ & $\mathrm{T} / \mathrm{C}$ & $\mathrm{R}$ \\
\hline (i) compreender a categorização gráfica e funcional das letras & $\mathrm{I} / \mathrm{T}$ & $\mathrm{T} / \mathrm{C}$ & $\mathrm{R}$ \\
\hline $\begin{array}{l}\text { (ii) conhecer e utilizar diferentes tipos de letras (de forma e } \\
\text { cursiva) }\end{array}$ & $\mathrm{I} / \mathrm{T}$ & $\mathrm{T} / \mathrm{C}$ & $\mathrm{R}$ \\
\hline Compreender a natureza alfabética do sistema de escrita & $\mathrm{I} / \mathrm{T}$ & $\mathrm{T} / \mathrm{C}$ & $\mathrm{R}$ \\
\hline Dominar as relações entre grafemos e fonemas & I & $\mathrm{T} / \mathrm{C}$ & $\mathrm{T} / \mathrm{C}$ \\
\hline (i) dominar regularidades ortográficas & I & $\mathrm{T} / \mathrm{C}$ & $\mathrm{T} / \mathrm{C}$ \\
\hline (ii) dominar irregularidades ortográficas & I & $\mathrm{T} / \mathrm{C}$ & $\mathrm{T} / \mathrm{C}$ \\
\hline
\end{tabular}

Fonte: Brasil (2007, p.24).

Quadro 2 - Leitura: capacidades, conhecimentos e atitudes

\begin{tabular}{lcccc}
\hline Leitura: capacidades, conhecimentos e atitudes & & & \\
\hline CAPACIDADES, CONHECIMENTOS E ATITUDES & $1^{\circ}$ ano & $2^{\circ}$ ano & $3^{\circ}$ ano \\
\hline Desenvolver atitudes e disposições favoráveis à leitura & I/T/C & T/C & T/C \\
\hline Desenvolver capacidades de decifração: & I & T/C & T/C \\
\hline (i) saber decodificar palavras & I & T/C & T/C \\
\hline (ii) saber ler reconhecendo globalmente as palavras & I & T/C & T/C \\
\hline Desenvolver fluência em leitura & I & T & T/C \\
\hline Compreender textos & I/T/C & T/C & T/C \\
\hline
\end{tabular}




\section{Leitura: capacidades, conhecimentos e atitudes}

(i) identificar finalidades e funções de leitura, em função do reconhecimento do suporte, do gênero e da contextualização do texto

(ii) antecipar conteúdos de textos a serem lidos em função do seu suporte, seu gênero e sua contextualização

(iii) levantar e confirmar hipóteses relativas ao conteúdo do texto que está sendo lido

$\mathrm{I} / \mathrm{T} / \mathrm{C} \quad \mathrm{T} / \mathrm{C} \quad \mathrm{T} / \mathrm{C}$

$\mathrm{I} / \mathrm{T} / \mathrm{C} \quad \mathrm{T} / \mathrm{C} \quad \mathrm{T} / \mathrm{C}$

$\mathrm{I} / \mathrm{T} / \mathrm{C} \quad \mathrm{T} / \mathrm{C} \quad \mathrm{T} / \mathrm{C}$

(iv) buscar pistas textuais, intertextuais e contextuais para ler nas

I/T/C T/C T/C

entrelinhas (fazer inferências), buscando a compreensão

(v) construir compreensão global do texto lido, unificando e inter-relacionando informações explícitas e implícitas

I/T/C T/C T/C

(vi) avaliar ética e afetivamente o texto, fazer extrapolações

$\mathrm{I} / \mathrm{T} / \mathrm{C} \quad \mathrm{T} / \mathrm{C} \quad \mathrm{T} / \mathrm{C}$

Fonte: Brasil (2007, p.40).

Observamos que, no primeiro quadro, há um enfoque no desenvolvimento das capacidades, habilidades e conhecimentos ligados à codificação e à decodificação. Vemos, nessas habilidades, relação com as dimensões cognitiva e linguística envolvidas no ato de ler. Já, no segundo quadro, as habilidades reiteram processos cognitivos de construção de sentidos e avançam para usos sociais da leitura, ligados à dimensão sociocultural da leitura.

Quadro 3 - Práticas de leitura

\begin{tabular}{|l|c:c|}
\hline 2. PRÁTICAS DE LEITURA & $\begin{array}{c}1 \text { o } \\
\text { ano }\end{array}$ & $\begin{array}{c}\mathbf{2}^{\mathbf{o}} \\
\text { ano }\end{array}$ \\
\hline Leitura como fonte de informação, fruição, imaginação, etc. & $\mathrm{X}$ & $\mathrm{x}$ \\
\hline Leitura (inicialmente pelo/a professor/a de variados gêneros textuais* & $\mathrm{X}$ & $\mathrm{X}$ \\
\hline Compreensão de textos* & $\mathrm{X}$ & $\mathrm{X}$ \\
\hline Análise e discussão de textos lidos* & $\mathrm{X}$ & $\mathrm{X}$ \\
\hline Uso real das diversas dimensões sociais da leitura* & $\mathrm{X}$ & $\mathrm{X}$ \\
\hline
\end{tabular}

* intensificar no $2^{\circ}$ ano

Fonte: São José (2008, p.55). 
Quadro 4 - Práticas de escrita e análise linguística

\begin{tabular}{|c|c|c|}
\hline 3. PRÁTICAS DE ESCRITA E ANÁLISE LINGUÍSTICA & $\begin{array}{c}1^{\circ} \\
\text { ano }\end{array}$ & $\begin{array}{c}2^{\mathrm{o}} \\
\text { ano }\end{array}$ \\
\hline Diferentes formas de representar idéias, situações & $\mathrm{x}$ & $\mathrm{x}$ \\
\hline Funções sociais da escrita & $\mathrm{x}$ & $\mathrm{x}$ \\
\hline Sistema de representação da escrita* & $\mathrm{x}$ & $\mathrm{x}$ \\
\hline Reestruturação de textos & $\mathrm{x}$ & $\mathrm{x}$ \\
\hline Sistematização de textos pequenos* & $\mathrm{x}$ & $\mathrm{x}$ \\
\hline Uso real das diversas dimensões sociais da escrita* & $\mathrm{x}$ & $\mathrm{x}$ \\
\hline
\end{tabular}

* intensificar no $2^{\circ}$ ano

Fonte: São José (2008, p.55)

De certa forma, as três dimensões envolvidas no ato da leitura estão também contempladas nos quadros do documento municipal, embora de forma não tão clara e esmiuçada quanto nos dois primeiros. Observamos as dimensões cognitiva e linguística representadas em itens como "Compreensão de textos" e "Sistema de representação da escrita", entre outros. Mas, aparentemente, o principal foco dos quadros no documento municipal reside na dimensão sociocultural da leitura, pois privilegia aspectos como "análise, discussão, uso das dimensões sociais de textos lidos", sem explicitar os aspectos cognitivos e linguísticos envolvidos, principalmente no processo de apropriação da leitura, uma vez que esse documento é dirigido ao professor alfabetizador. Abrimos aqui outro parêntese com outra ressalva: entendemos que as habilidades específicas requeridas pela alfabetização estejam implícitas nas habilidades descritas no quadro, mas entendemos também que há o risco de haver um "apagamento" da importância de tais habilidades; fazemos essa ressalva, pois concordamos com Soares (2003), que diz que a alfabetização deve ser ensinada de forma sistemática, ou seja, a "técnica de alfabetização" não deve ser relegada a segundo plano. Em outras palavras, as dimensões linguística e cognitiva não podem ser denegadas em função da dimensão sociocultural.

Novamente observamos a distinção entre as posições teóricas adotadas pelas duas diferentes instâncias; enquanto, no documento do MEC, cada uma das habilidades descritas nos quadros é esmiuçada, dando ênfase à apropriação do código alfabético propriamente dito (envolvendo trabalho com relação fonemas/grafemas, consciência fonológica, estrutura da língua escrita), as orientações dadas ao professor nos documentos municipais são amplas, no sentido de se trabalhar sempre a partir do texto (entendido como 
unidade de sentido e essencial para o trabalho com a língua escrita). Em relação específica à área de leitura, no documento norteador que acompanha o material do projeto de alfabetização, encontramos referências a teorizações de Geraldi (1993, 1996 apud SÃO JOSÉ, 2007): a leitura é uma interlocução que se estabelece entre sujeitos e, como tal, espaço de construção e circulação de sentidos, vinculada ao processo de constituição da subjetividade, ampliada pelas possibilidades de interação que as funções da escrita permitem. A leitura é novamente citada no capítulo referente às Orientações Metodológicas, também nessa visão mais ampla:

Da mesma forma, destaca-se a importância da leitura de imagens, pois ler palavras, obras de arte, imagens ou mesmo o mundo à nossa volta, exige mais do que apenas identificar o que é visto. O olhar de cada pessoa é diferente em função do que já conhece sobre o mundo. Cabe ao/a professor/a mediar e valorizar a expressão de cada criança, incentivando-a a prosseguir em suas interpretações. (SÃO JOSÉ, 2007, p.33).

Nas orientações sobre o trabalho com literatura, a leitura também é citada, com um enfoque ao estímulo e ao prazer pela leitura literária (leitura como fruição). As orientações ao professor alfabetizador destacam que leitura e escritura devem despertar o interesse, o prazer e a necessidade do seu uso pela criança, para que sua aprendizagem torne-se significativa. Nesse contexto, o aprendizado da língua escrita é apresentado como um processo complexo, que não se realiza a partir do simples contato com textos, mas envolve um planejamento sistemático; as orientações referentes a esse planejamento envolvem procedimentos metodológicos, o processo de apropriação dos sistemas de escrita e de leitura passa pelo desenvolvimento de atividades pensadas e planejadas que possibilitem às crianças desenvolverem a compreensão de tais sistemas e quais as normas que o regem, quais seus usos e funções na sociedade (SÃO JOSÉ, 2008), valorizando espaços, tempos e rotinas das atividades diárias e semanais (agenda, calendário, roda de conversa, organização da sala, uso da literatura, visitas à biblioteca, registro do professor, avaliação das atividades, portfólio).

Após essa breve análise dos principais documentos que orientam a prática do professor alfabetizador, podemos começar a pensar como eles refletem na avaliação da Provinha Brasil, o indicador oficial acerca da alfabetização. Se a Provinha Brasil é baseada, elaborada e estruturada também a partir dos pressupostos teóricos defendidos pelo Pró-Letramento, que, em nossa interpretação, focam as três dimensões da leitura (sociocultural, cognitiva e linguística), e, se os documentos municipais, tal qual decorre de nossa interpretação, ancoram-se, principalmente, na dimensão sociocultural, 
como essas diferentes posturas teóricas se evidenciam no desempenho das crianças nessa avaliação? Uma vez que, adotando a postura de pesquisadoras participantes, percebemos que as orientações municipais parecem incidir no cotidiano escolar, supomos encontrar dissonâncias, refletidas tanto em itens pontuais (habilidades específicas), quanto no conjunto geral de habilidades avaliadas na Provinha Brasil.

\section{A Provinha Brasil: situando a avaliação e sua aplicação na prática}

A Provinha Brasil é um teste padronizado, elaborado pelo MEC, mais precisamente pelo INEP (Instituto de Pesquisas Anísio Teixeira), aplicado às crianças de todo o país. A Provinha é uma avaliação diagnóstica, realizada mediante adesão das respectivas redes municipais, e seus resultados não compõem os indicadores nacionais. Atendendo a uma meta estabelecida no Plano Nacional de Educação, visando a investigar habilidades relacionadas ao processo de alfabetização, a Provinha Brasil norteia-se a partir dos seguintes objetivos: avaliar o nível de alfabetização dos educandos nos anos iniciais do ensino fundamental; oferecer às redes de ensino um resultado da qualidade da alfabetização, prevenindo, assim, o diagnóstico tardio dos déficits de letramento; contribuir para a melhoria da qualidade de ensino e para a redução das desigualdades, em consonância com as metas e políticas estabelecidas pelas diretrizes da educação nacional (BRASIL, 2009b, p.7).

Propõe, também, que os resultados ajudem a compreender os conhecimentos que os alunos já adquiriram sobre a língua escrita, bem como quais aspectos dos conteúdos ainda deverão ser desenvolvidos; também se espera que os resultados contribuam para o aperfeiçoamento, reorientação e redimensionamento da prática pedagógica do professor, visando à redução das desigualdades e à melhoria da qualidade de ensino.

A Provinha Brasil também traz contribuições para a organização da alfabetização e do letramento, apresentando essas contribuições em forma de questionamentos: Quais capacidades de leitura os alunos dominam? Quais capacidades de leitura a escola agregou ao desempenho de seus alunos em um ano de escolaridade? Quais dificuldades em leitura os alunos apresentam ao final de dois anos de escolaridade? Quais capacidades necessitam ser consolidadas nos anos iniciais do Ensino Fundamental? (BRASIL, 2009a, p.7).

Seu público alvo são os alunos que estão no início do segundo ano de escolarização, ${ }^{5}$ pois, nessa população, é possível verificar o processo de apropriação

O segundo ano de escolaridade, em 2009, na rede municipal de ensino em questão, corresponde ao $2^{\circ}$ ano do

Ensino Fundamental. 
das habilidades de leitura e algumas habilidades de escrita por parte dos alunos desde o início de seu processo de alfabetização.

Seu foco de avaliação são as habilidades relativas à alfabetização e ao letramento inicial dos estudantes. Da mesma forma que no PróLetramento, na elaboração da Provinha Brasil, a alfabetização é concebida como "desenvolvimento da compreensão de regras de funcionamento do sistema de escrita alfabética" e letramento, como "as possibilidades de usos e funções sociais da linguagem escrita, isto é, o processo de inserção e participação dos sujeitos na cultura escrita" (BRASIL, 2009b, p.11) e um de seus pressupostos fundamentais é que "a alfabetização e o letramento são processos complementares e inseparáveis" (BRASIL, 2009c, p.7). Assim, as habilidades foram agrupadas em: (i) compreensão e valorização da cultura escrita, (ii) apropriação do sistema de escrita, (iii) leitura, (iv) escrita e (v) desenvolvimento da oralidade; porém, devido às características da Provinha Brasil, apenas os três primeiros eixos são contempladas na avaliação.

A Provinha, então, é composta por 24 questões de múltipla escolha; algumas delas são integralmente lidas pelo professor; outras, parcialmente; umas devem ser lidas apenas pelos alunos (individualmente e em silêncio). As orientações quanto à leitura ou não das questões por parte do professor são dadas no "Guia do Professor(a) Aplicador(a)" (BRASIL, 2009c) e são específicas para cada questão.

A correção da Provinha baseia-se em gabaritos, e o número de acertos por criança é agrupado em níveis de desempenho: iniciando no nível 1 (até 10 acertos) até o nível 5 (de 23 a 24 acertos). Para cada nível, são apontadas características comuns das habilidades já desenvolvidas, bem como são destacadas aquelas que ainda devem ser trabalhadas (BRASIL, 2009d).

\section{A aplicação da Provinha Brasil}

Apresentamos, aqui, alguns aspectos de leitura contemplados na Provinha Brasil, principalmente em relação à proficiência em leitura (dimensionada sociocultural, linguística e cognitivamente); para tanto, analisamos também os resultados apresentados, nesta avaliação, por alunos de $2^{\circ}$ ano de uma escola pública da Grande Florianópolis. Participaram dessa avaliação 94 alunos, distribuídos em cinco turmas diferentes, regidas por quatro professoras (uma delas atende a duas turmas; outra, ao período matutino e a seguinte, ao vespertino).

Essas turmas estão inseridas no novo currículo do Ensino Fundamental de nove anos, organizado em quatro grandes áreas: Linguagens, Ciências Naturais, 
Ciências Lógico-Matemáticas e Ciências Sociais, e estão sendo alfabetizadas por meio de um projeto desenvolvido pela SME cujas orientações e metodologias, especificadas em documentos norteadores, em formações continuadas e em orientações sistemáticas e presenciais às escolas, todos os professores são convidados a adotar. As atividades pedagógicas são organizadas através de temáticas definidas nos documentos norteadores (SÃO JOSÉ, 2007); dentro de cada temática, os professores são convidados pela equipe pedagógica da escola a elaborar as sequências didáticas para cada série, de forma conjunta. Os livros didáticos escolhidos pelo Programa Nacional do Livro Didático ${ }^{6}$ são utilizados como material de apoio e complementar às temáticas.

A Provinha Brasil foi aplicada, na escola focalizada neste estudo, pela própria professora da turma; foi acompanhada por uma pessoa da equipe pedagógica da própria escola e por um representante da SME. As crianças foram motivadas a responder à prova sem cobranças e/ou notas; muitas delas já haviam visto a propaganda institucional veiculada na televisão e, de modo geral, gostaram muito de responder à Provinha. A metodologia de aplicação seguiu, rigorosamente, as orientações previstas pela própria Provinha, embora, em uma das turmas avaliadas, a metodologia não tenha sido seguida à risca, já que a professora aplicadora leu todas as questões e alternativas, inclusive os textos que servem de base às interpretações. Esses resultados não foram excluídos, pois fornecem também dados a quem se propõe estudar os diversos aspectos do ensino da leitura, mas são apresentados separadamente (chamada turma 5), pois não são passíveis de comparação por terem diferentes metodologias de aplicação. Apesar de não termos excluído a turma 5 das análises; para fins de cálculo de médias (apresentadas na Tabela 1 e discutidas ao longo do artigo), essa turma foi excluída.

\section{Os resultados da Provinha Brasil nas cinco turmas analisadas}

Os resultados das cinco turmas que serão utilizados para a discussão das questões da Provinha encontram-se na Figura 1 e na Tabela 1.

No triênio em questão (2008-2010), o livro didático de Alfabetização adotado pertence à Coleção "A Grande Aventura", confira Carvalho e Anson (2005). 
Figura 1 - Porcentagem de acertos das questões da

Provinha Brasil, por turmas e média das turmas

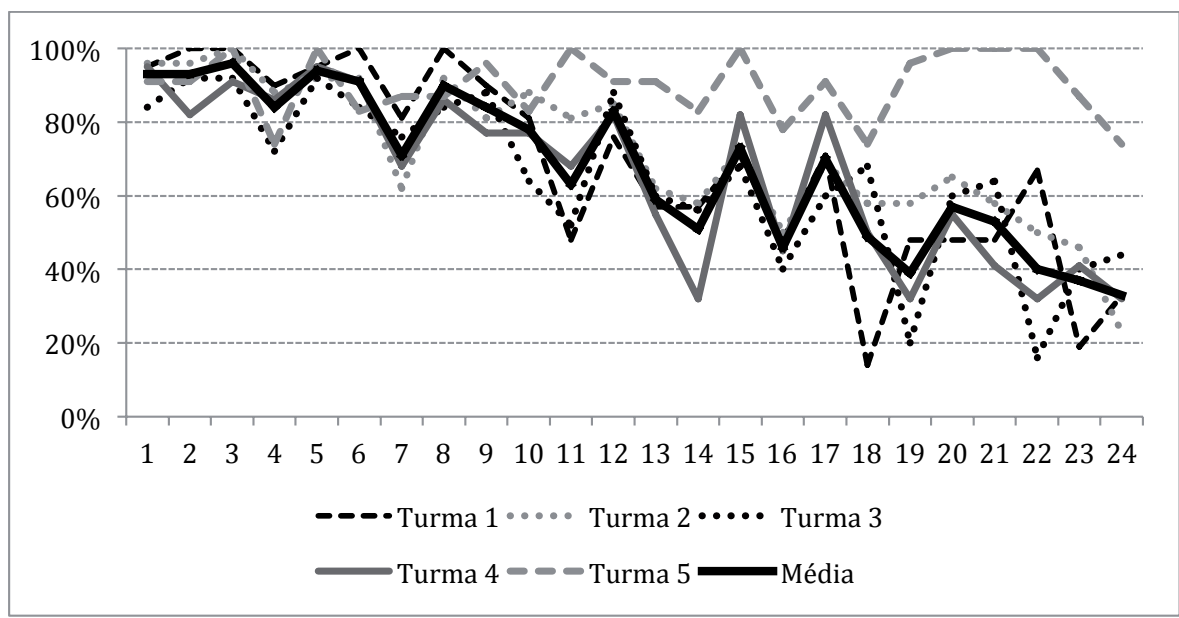

Fonte: Elaboração própria.

Tabela 1 - Classificação nos níveis, média de acertos e nível médio das turmas do $2^{\circ} \mathrm{ano}^{7}$

\begin{tabular}{ccccccccccccc}
\hline & & Turma 1 & Turma 2 & Turma 3 & Turma 4 & Turma 5 & $\begin{array}{c}\text { Total 2 } \\
\text { ano }\end{array}$ \\
\cline { 2 - 13 } & NA & NR & NA & NR & NA & NR & NA & NR & NA & NR & NA & NR \\
\hline Nível 1 & 1 & $5 \%$ & 4 & $15 \%$ & 2 & $8 \%$ & 1 & $5 \%$ & 0 & 0 & 8 & $9 \%$ \\
\hline Nível 2 & 7 & $33 \%$ & 3 & $12 \%$ & 12 & $48 \%$ & 10 & $45 \%$ & 0 & 0 & 32 & $34 \%$ \\
\hline Nível 3 & 5 & $24 \%$ & 8 & $31 \%$ & 5 & $20 \%$ & 3 & $14 \%$ & 3 & $13 \%$ & 21 & $22 \%$ \\
\hline Nível 4 & 7 & $33 \%$ & 7 & $27 \%$ & 4 & $16 \%$ & 7 & $32 \%$ & 9 & $39 \%$ & 25 & $27 \%$ \\
\hline Nível 5 & 1 & $5 \%$ & 4 & $15 \%$ & 2 & $8 \%$ & 1 & $5 \%$ & 11 & $48 \%$ & 8 & $9 \%$ \\
\hline Total & 21 & $100 \%$ & 26 & $100 \%$ & 25 & $100 \%$ & 22 & $100 \%$ & 23 & $100 \%$ & $\mathbf{9 4}$ & $\mathbf{1 0 0 \%}$ \\
\hline Média & 16,38 & 17,23 & 15,64 & 15,77 & 21,57 & 16,26 \\
\hline Nível & 3 & 3 & 3 & 3 & & 4 & 3 & 3 \\
\hline
\end{tabular}

Fonte: Elaboração própria.

NA = número absoluto, refere-se à quantidade de alunos; NR = número relativo, refere-se à porcentagem. 
Na Figura 1, são representadas as porcentagens de acertos nas 24 questões da Provinha Brasil; observamos, na linha tracejada cinza, o melhor desempenho da turma na qual a professora leu a prova na íntegra. A linha preta (mais espessa) representa a média das outras quatro turmas. Observamos uma significativa queda no desempenho geral, de certa forma já esperado, pois a Provinha está organizada num crescendo de complexidade e, consequentemente, as últimas questões são as que ofereceriam maior dificuldade às crianças.

Observamos, na Tabela 1, que, em média, as crianças que responderam à Provinha Brasil estão classificadas no Nível 3, como aponta a última linha inferior da tabela - dentre as cinco turmas, quatro delas classificam-se no nível 3; porém uma observação mais criteriosa da mesma tabela -, observando, agora, não a linha final inferior, mas a coluna final à direita, que aponta que 34\% das crianças, ou seja, a maior parcela das crianças que responderam à Provinha está classificada no Nível 2.

Ainda, se somarmos as crianças que se encontram acima (níveis 4 e 5) e abaixo (níveis 1 e 2) da média, observamos que $45 \%$ delas estão classificadas nos dois primeiros níveis, e 36\%, nos dois últimos níveis; ou seja, ao mesmo tempo em que encontramos crianças que obtiveram excelente desempenho, na ótica da avaliação da Provinha Brasil, encontramos um número bastante considerável (40 crianças que correspondem a $45 \%$ do total) que se encontram nos níveis primários de alfabetização.

Para o professor alfabetizador, esse dado, por si só, já é riquíssimo, pois mostra a heterogeneidade das crianças, ou seja, já confirma a necessidade de considerar os sujeitos em sua individualidade, como preconiza a teoria vigotskiana (através dos conceitos de zonas de desenvolvimento) e o modelo ideológico de letramento (STREET, 2003).

Ainda de acordo com o guia de correção (BRASIL, 2009d, p.11), crianças que atingiram o nível 3 (de 16 a 18 acertos) já "consolidaram a capacidade de ler palavras de diferentes tamanhos e padrões silábicos, conseguem ler frases com sintaxe simples (sujeito + verbo + objeto) e utilizam algumas estratégias que permitem ler textos de curta extensão". As capacidades reveladas pelo nível 3 são: ler palavras mais complexas, constituídas por letras que representam mais de um som e por sílabas formadas por dígrafos, encontros consonantais ou encontros vocálicos; ler frases curtas; localizar informações explícitas por meio de leitura silenciosa em uma frase ou em textos de aproximadamente cinco linhas; reconhecer o assunto do texto com base na leitura de informações evidentes no título; identificar finalidade de gêneros (convite, anúncio publicitário), apoiandose ou não em suas características gráficas como imagens e em seu modo de apresentação. Como sugestão de atividades para crianças que demonstram essas habilidades, a intensificação do trabalho com gêneros textuais (iniciando pelos 
mais cotidianos até evoluir aos menos familiares), buscando atingir a fluência em leitura.

Já crianças que atingiram o nível 2 desenvolveram habilidades referentes ao conhecimento e uso do sistema da escrita e associam adequadamente grafemas e fonemas, mas apresentam dificuldades na leitura de palavras com ortografia mais complexa, demonstrando ter adquirido as seguintes habilidades: ler algumas palavras compostas por sílabas formadas por consoante/vocal/consoante ou por consoante/consoante/vogal; reconhecer letras escritas de diferentes formas; identificar o número de sílabas de uma palavra formada por sílabas simples e com grafemas correspondentes a um único som; reconhecer a finalidade do texto com apoio das características gráficas; reconhecer o valor sonoro de uma sílaba; reconhecer o assunto de gêneros textuais mais próprios do contexto escolar com base em suas características gráficas. Como sugestões para o trabalho com alunos do nível 2, estão orientações para o domínio das regularidades e das irregularidades ortográficas da língua portuguesa e o conhecimento de diferentes gêneros e diferentes estruturas textuais (BRASIL, 2009d).

\section{Reflexões acerca dos resultados da Provinha Brasil}

Um dos primeiros questionamentos acerca da Provinha refere-se às características das questões e às habilidades que nelas estão sendo avaliadas. Na busca dessas respostas, criamos duas categorias de análise: "questões focadas nas habilidades de decodificação" (nas quais observamos predomínio das dimensões linguística e cognitivas da leitura), e "questões envolvendo textualização" (nas quais observamos uma convergência entre as dimensões linguística, cognitiva e sociocultural implicadas na compreensão leitora) e classificamos as questões da Provinha Brasil nessas duas grandes categorias, tomando por base justamente as características da questão e as habilidades requeridas por ela. ${ }^{8}$

Assim, na categoria "questões focadas nas habilidades de decodificação" agrupamos treze questões (1, 2, 3, 4, 6, 7, 8, 9, 10, 12, 13, 14 e 15). Em todas, o foco recai sobre o código escrito e algumas de suas particularidades, principalmente a habilidade de decodificação de palavras isoladas (em 7 das 14 questões); outras habilidades requeridas são reconhecimento de letras isoladas, identificação da letra inicial da palavra, contagem do número de sílabas, aliteração da sílaba inicial, reconhecimento das diversas fontes de escrita, identificação da sílaba final, localização da palavra em uma frase, com cada uma dessas habilidades sendo testada em uma questão diferente.

Esta classificação foi elaborada especialmente para este artigo pelos pesquisadores, sem correspondentes teóricos. 
Na categoria "questões envolvendo textualização", foram agrupadas as outras onze questões que têm enfoque voltado para leitura, textualização, interpretação e compreensão (5, 11, 16, 17, 18, 19, 20, 21, 22, 23 e 24). A primeira envolvendo textualização é a $7^{a}$, que solicita que se identifique, entre várias placas de identificação, em qual delas há somente letras. ${ }^{9}$ Nas demais, encontram-se vários gêneros (fábulas, textos científicos, recados, convites, pequenas historietas, anedota) em vários suportes (reproduzidos na provinha - cartaz de campanha de vacinação, capa de revista). Na maioria das nove questões aqui analisadas (cinco), a habilidade requerida dos alunos é localizar a informação em um texto, inclusive em textos mais extensos (a exemplo das últimas quatro questões da Provinha); em outra, é solicitado o assunto principal do texto (capacidade de síntese ou de elaborar uma macroestrutura do texto) e, em outra, a capacidade de inferenciação a partir das informações contidas no texto. Duas outras questões envolvem a pergunta "Para que serve este texto?", ou seja, envolvem habilidades relacionadas à identificação da funcionalidade interacional do texto, na esfera em que circula.

Assim, embora as orientações oficiais referentes ao processo de alfabetização enfoquem a necessidade do trabalho com o texto e em atividades contextualizadas, encontramos, na Provinha Brasil, 24 questões com 24 temas diferentes, com a maioria delas focadas nas habilidades de reconhecimento e manipulação do código. Além disso, nas atividades que envolvem as habilidades de textualização, mesmo apresentando gêneros de ampla circulação social, cada questão compõese individualmente, sem haver a preocupação de contextualizar a esfera de circulação desses gêneros.

Feitas essas considerações acerca de nossa classificação e as implicações que vemos nela, a partir daqui apresentaremos e analisaremos os resultados dos alunos envolvidos na avaliação, mantendo a distinção entre as questões.

\section{Questões focadas nas habilidades de decodificação: interface das dimensões linguística e cognitiva implicadas no domínio do sistema alfabético}

De modo geral, o desempenho dos alunos nessas questões foi bom, com média de 80\% de acertos nas turmas que responderam à Provinha seguindo as orientações metodológicas (embora nenhuma questão tenha atingido 100\% de aproveitamento nas quatro turmas) e 89\% de acertos na turma na qual a professora leu todos os enunciados, alternativas e textos para os alunos. Dentro dessas médias, algumas tiveram porcentagens de acerto melhores (acima de 90\%), todas

Classificamos essa questão como envolvendo textualização, pois nos embasamos no fato de que as placas implicam contextos de sentido, mesmo que a habilidade requerida nela não demande um processo de textualização propriamente dita. 
envolvendo a decodificação de palavras isoladas (MALA, RATO, BICICLETA, PANELA, FORMIGUINHA); outras questões que também envolvem palavras isoladas (CACHORRO e LATA) tiveram porcentagens boas, mas abaixo de 90\%.

Ressalta-se que, nas primeiras questões, as alternativas apresentadas às crianças ou diferiam totalmente entre si, ou diferiam na primeira letra ou sílaba (por exemplo, as alternativas para a palavra RATO eram GATO, PATO, RATO e TATO); nas duas últimas, as alternativas mantinham o mesmo número de sílabas, iniciavam pela mesma sílaba, mas diferiam ou nas demais sílabas ou apenas no grafema medial (palavra LATA, alternativas LAMA, LAPA, LARA e LATA). Daquelas que envolvem somente a decifração, esta última foi a que apresentou o maior nível de dificuldade para as crianças, com 78\% de acertos.

Quando foram solicitadas habilidades específicas, o desempenho das crianças manteve-se bom, porém algumas questões apresentaram porcentagens de acertos relativamente inferiores. Neste primeiro bloco, uma dessas questões, que teve o menor desempenho ( $51 \%$ de acertos), envolve o reconhecimento das diversas fontes de escrita; a questão 14 pede que a criança identifique em qual alternativa a mesma palavra aparece grafada várias vezes, envolvendo letras maiúsculas, letras cursivas e letras iniciais maiúsculas e minúsculas. Considerase que essa porcentagem de acertos não é satisfatória, pois praticamente a metade das crianças dos $2^{\circ}$ anos não reconheceu as diversas fontes da escrita. Olhando somente para as respostas erradas, observa-se que 68\% das crianças que erraram essa questão assinalaram a alternativa que continha quatro palavras diversas (inclusive com padrão silábico, número de sílabas e tonicidade diferentes), porém todas iniciadas por " $\mathrm{CH}$ "; este número leva-nos a pensar que as crianças responderam à questão baseadas apenas no aspecto visual das letras. Nas fontes escolhidas, a letra "B" apresenta características visuais bastante diversas quando em maiúsculas e minúsculas e/ou quando em letras maiúsculas ou cursiva; na alternativa escolhida pelas crianças, a letra " $C$ " não apresenta tantas variações, o que poderia justificar sua escolha. Mesmo assim, essa é uma análise ainda lacunar, uma vez que envolve somente a primeira letra das palavras, e a leitura de uma palavra não é dada somente pela primeira letra.

Esses resultados, porém, também parecem refletir as orientações recebidas pelos professores (tanto claramente pela assessoria da Secretaria quanto pelo "currículo oculto"10 existente na escola), principalmente do $1^{\circ}$ ano, os quais sugerem que o professor escreva sempre em letras maiúsculas, tanto no quadro e no caderno do aluno quanto nas atividades reproduzidas a partir de fotocópias e nos materiais expostos em sala de aula, e que a letra cursiva seja introduzida somente a partir do $3^{\circ}$ ano. Observamos aqui uma possível dissonância entre

10 Segundo Silva (2002) o "currículo oculto" engloba aspectos do ambiente escolar que, mesmo não fazendo parte do currículo oficial, explícito, encontram-se presente nas escolas, influenciando na aprendizagem dos alunos. 
as orientações das diversas instâncias (federal e municipal); no Pró-Letramento (BRASIL, 2007, p.30), encontramos a seguinte orientação: "não é recomendável que, em nome da facilidade de usar só um tipo de letra, se impeça o contato dos alunos com textos e impressos com outros tipos de letras, que circulem socialmente em diversos suportes, cumprindo diferentes funções".

Outras questões que refletem essa distinção de posições teóricas são as que envolvem questões metalinguísticas, como a identificação do número de sílabas de uma palavra, da primeira letra da palavra, da última sílaba da palavra alvo e, principalmente, da questão que envolve aliteração (consciência fonológica).

Apesar de a Provinha Brasil constituir um teste escrito, trazemos à discussão noções de consciência fonológica por acreditarmos nas relações de mútua influência entre o desenvolvimento dessa e a instrução alfabética; assim, a consciência de sílabas na oralidade e o reconhecimento da sílaba na escrita parecem ser interdependentes.

Quando uma criança aprende a escrever uma língua que tem por base um sistema alfabético, necessita compreender que as letras, enquanto signos gráficos, correspondem a segmentos sonoros que não possuem significados em si mesmos, habilidades estas relacionadas à chamada consciência fonológica. Consciência fonológica é parte da consciência linguística, que implica a capacidade de compreender a maneira pela qual a linguagem oral pode ser dividida em componentes cada vez menores (sentenças em palavras, palavras em sílabas e sílabas em fonemas), de refletir explicitamente sobre os sons da língua, operar com essas unidades e manipulá-las de maneira diferenciada. O desenvolvimento da consciência fonológica em crianças obedece a padrões de complexidade; alguns níveis de consciência fonológica podem ser desenvolvidos espontaneamente, independentemente do ensino formal da escrita, porém habilidades fonológicas mais elaboradas têm sido consideradas como dependentes dos próprios avanços que a criança realiza em termos de alfabetização. As habilidades menos complexas são a recepção de rimas e aliteração e a segmentação de sentenças em palavras, que contribuem para os estágios iniciais da leitura; num processo recíproco, as habilidades desenvolvidas na leitura contribuem para o desenvolvimento de habilidades fonológicas mais complexas, como a manipulação e transposição fonêmicas (MALUF e BARRERA, 1997; ALVAREZ, 1998; CARVALHO; ALVAREZ, 2000; ZORZI, 2002).

Na questão que envolve a identificação do número de sílabas (questão 12), os alunos apresentaram um bom desempenho, atingindo 83\% de acertos; ressaltamos que todas as crianças que erraram essa questão assinalaram a alternativa D - (6), muito provavelmente confundindo número de sílabas com número de grafemas (ou fonemas, que, nesse caso, coincidem). Como o trabalho com divisão silábica tende a ser uma prática corriqueira e tradicional da escola, as crianças não tiveram 
dificuldade em segmentar a palavra SAPATO em sílabas, até porque segue o padrão silábico canônico (consoante+vogal).

Mas não observamos o mesmo nas demais questões de reflexão metalinguística: já na questão 7, que envolve a identificação da primeira letra da palavra alvo (no caso, CAMA), a porcentagem de acertos caiu para 71\%, o que soa incoerente, pois observamos que, no dia a dia das salas de aula, várias atividades envolvem a identificação das letras: a primeira letra dos nomes das próprias crianças, dos brinquedos, das figuras; relacionar e identificar a primeira letra de palavras é uma atividade bastante corriqueira em sala de aula.

Assim, uma possível explicação para essa queda no desempenho pode estar na complexidade das relações grafema/fonema, aqui aplicada principalmente à decodificação; o grafema " C" possui seu correspondente fonêmico dependente do contexto grafêmico, podendo representar os fonemas /s/ e /k/ (SCLIAR-CABRAL, 2003). ${ }^{11}$ Interessante também pensarmos sobre as hipóteses das crianças, partindo das respostas erradas: 85\% das respostas equivocadas optaram pela primeira alternativa $(\mathrm{M})$. Ainda em relação à complexidade das relações grafema/fonema, embora o grafema " $\mathrm{M}$ " também tenha seu correspondente fonêmico dependente do contexto (SCLIAR-CABRAL, 2003), quando no início de sílaba tem sempre como correspondente o fonema $/ \mathrm{m} /$.

Ou mais... Será que essas crianças simplesmente assinalaram a primeira alternativa? Essa postura refletiria talvez uma simples exaustão por parte das crianças? Ou uma outra hipótese: Será que os alunos identificaram corretamente o desenho? Reconheceram a figura como uma "cama" ou ficaram em dúvida em relação ao objeto apresentado na Provinha, recortando, por exemplo, um dos componentes do desenho? Mais uma vez, a necessidade de entendermos a dimensão sociocultural da leitura...

A situação é mais clara na questão 15, que solicita que as crianças apontem qual a última sílaba da figura que representa a palavra alvo (BORBOLETA). Ao solicitar que a criança reconheça a última sílaba da figura (borboleta), sem que haja a leitura (apoio oral auditivo), a questão envolve um grau de abstração, atenção e consciência de sílabas. Como opções, estão colocadas todas as sílabas da figura, o que poderia levar a criança a assinalar como alternativa correta a primeira opção, que coincide com a primeira sílaba (BOR), atividade corriqueira em sala de aula

11 Regra de descodificação, de correspondência grafo-fonêmicas dependentes do contexto grafêmico - grafemas "c", "sc"e "xc" (SCLIAR-CABRAL, 2003, p.84):

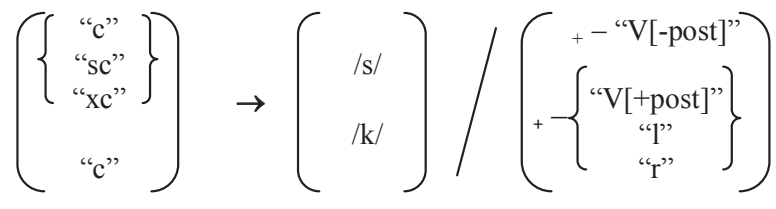


(tanto que 53\% das respostas erradas assinalaram essa alternativa). A porcentagem de acertos desta questão foi igual a 72\%, o que indicaria que os alunos tiveram uma relativa dificuldade em operar com as noções exigidas pela questão. Como a turma na qual a professora leu a questão inteira para os alunos teve 100\% de acertos, infere-se que o apoio auditivo, somado à ênfase dada pela professora na palavra "última" do enunciado da questão, facilitou em muito sua resolução, pois ofereceu pistas aos alunos.

A última das questões baseadas no código e que envolvem reflexões metalinguísticas é a que solicita a habilidade de aliteração e que apresentou a menor porcentagem de acertos: 59\% e, consequentemente, representa a questão com maior dificuldade para as crianças. Nesta questão, as crianças devem apontar qual a palavra que alitera (aliteração silábica ou seja, isolar o segmento fonológico, no caso a sílaba, compartilhado pelas palavras (MALUF; BARRERA, 1997) com a palavra alvo (apresentada somente em forma de figura); é uma questão complexa, embora a resposta possa ter sido apoiada também na escrita (jacaré - janela) e pela própria organização da questão: a criança tem que reconhecer um item não verbal (a figura), transpô-la ao plano verbal oral, operar metalinguisticamente sobre ele e, finalmente, transpô-la para o plano verbal escrito para então associar com a sílaba alvo. Novamente, a turma na qual a professora leu todas as alternativas para os alunos leva-nos a reflexões interessantes; essa turma obteve 100\% de aproveitamento, o que nos levaria a crer que as respostas foram sim baseadas na consciência fonológica (relação grafema/fonema e aliteração) e não na escrita. Se, ouvindo a palavra pronunciada de forma enfática pela professora as crianças responderam corretamente a questão e "lendo" de forma autônoma seu desempenho caiu, infere-se que a lógica de respostas baseia-se mais no som das palavras do que em sua escrita, o que nos parece exemplo de mútua relação entre consciência de sílaba e instrução alfabética, sobretudo considerando que há uma implicação de consciência de sílaba. Outro dado que nos leva a descartar o apoio na escrita é a análise dos erros; não observamos um "padrão de erro" para essa questão (35\% assinalaram GALINHA, 35\% CHÁCARA e 30\% JIBOIA); se houvesse o apoio na escrita, poderíamos esperar que a maioria das crianças opta-se pela alternativa JIBOIA, uma vez que inicia pela mesma letra da figura em questão.

\section{Questões envolvendo textualização: convergência entre as dimensões linguística, cognitiva e sociocultural implicadas na compreensão leitora em contextos interacionais de uso da escrita}

Se, nas questões com ênfase no código o desempenho dos alunos foi bom, o mesmo não pode ser dito nas questões envolvendo a textualização. Foram 
classificadas aqui as questões 5, 11, 16, 17, 18, 19, 20, 21, 22, 23 e 24, e a média de acertos nessas dez questões foi de $53 \%$.

Sabemos que a Provinha foi organizada em um crescendo de dificuldades, concentrando as questões envolvendo textualização na porção final da avaliação, o que pode, também, implicar cansaço e perda de interesse por parte das crianças. Talvez uma sugestão seria rever esta metodologia, mesclando graus de complexidade diferentes ou apresentando as questões de maneira randômica (o que inviabilizaria a orientação de todas as crianças responderem as questões ao mesmo tempo, sob a orientação da professora).

Mesmo reconhecendo a possibilidade de ter havido "desgaste" das crianças, inferimos que não seja um fator determinante para o bom (ou mau) desempenho das crianças, apoiados, novamente, nos dados da turma na qual a professora leu as questões na íntegra. Nessa turma, nas questões de textualidade, a porcentagem de acertos cresceu para 91\%. Tal porcentagem nessa turma é, inclusive, superior àquela obtida nas questões com ênfase no código. Assim, outros fatores podem ser levantados, se evocado o objetivo da Provinha e deste artigo: refletir sobre o processo de alfabetização dos alunos. O fato de a professora ter lido viabilizou às crianças o processo de construção de sentidos na oralidade, ou seja, não precisariam necessariamente estar alfabetizadas para responder de modo apropriado; o que foi testado, aqui, foi a atenção e a habilidade de escuta.

Essas duas habilidades de compreensão, do texto lido e do texto ouvido, foram exploradas por Megherbi (2009); segundo a autora, em leitores proficientes, a compreensão da linguagem lida é muito próxima da compreensão da linguagem falada, o que não é observado na criança que está se apropriando do sistema de escrita. Essa menor performance na compreensão de leitura em crianças que estão aprendendo a ler pode ser explicada pela demanda em decodificar e identificar as palavras do texto (a decodificação é uma habilidade específica da linguagem escrita) e pelo fato de que as crianças, antes de aprenderem a ler, estão expostas diariamente a situações cotidianas que envolvem e exigem habilidades de compreensão da linguagem falada.

Voltando à Provinha, dentre as questões envolvendo a textualização, a que apresentou melhores pontuações foi a que solicitava que o aluno reconhecesse, entre diversos portadores de texto qual deles possui apenas letras (Questão 5). A porcentagem de acertos foi elevada (94\%) e, dentre as crianças que erraram a questão, 60\% assinalaram a placa de automóvel como alternativa correta. Embora essa questão tenha sido classificada como atividade de textualização - o que decorre de as imagens corresponderem a potenciais usos sociais da escrita e não a palavras ou sentenças isoladas -, seu foco está em discriminar e diferenciar letras e números, não requerendo, necessariamente, a leitura dos textos, o que explicaria a diferença de desempenho em relação às demais questões. 
Uma outra questão (Questão 17) classificada como envolvendo textualidade, na verdade, traz para leitura uma pequena frase (sem apoio de ilustrações), que demanda duas atividades e deve ser lida de maneira autônoma pela criança. Mesmo assim, optamos por classificá-la como envolvendo textualização, pois contém uma sentença inteira com uma afirmação, cujo sentido deve ser resgatado. A questão pede que os alunos apontem o que Marina faz, escolhendo a alternativa que reproduz exatamente as palavras da frase, apenas alterando o verbo nos distratores, inclusive mantendo a grafia em caixa alta. Mesmo assim, a porcentagem de acertos ficou aquém do esperado, com apenas 70\% de acertos; novamente, na turma que teve o texto lido pela professora, a porcentagem de acertos foi bem maior: 91\%.

Embora as palavras do texto respeitem o padrão canônico de sílaba do português, o que seria um facilitador para o leitor iniciante, parece que os alunos ainda não dominam os processos de construção de sentidos no material escrito. As respostas dos alunos que erraram a questão, quando a professora não leu o texto para as crianças, mostram porcentagens equilibradas: 38\% responderam "MARINA MOSTRA A BONECA", 38\%, "MARINA PERDE A BONECA" e 24\%, "MARINA JOGA A BONECA". Será que as crianças leram as alternativas ou apenas assinalaram uma resposta ao acaso? Quando a professora leu o texto para as crianças, apenas uma errou a resposta, assinalando a primeira alternativa disponível.

Se nossa classificação das questões fosse revista, e essas duas questões não forem classificadas como textualização, esta categoria contaria somente com nove questões, ou seja, cerca de um terço da Provinha estaria focada em textualidade, e a porcentagem média de acertos nas questões envolvendo textualização cairia de $53 \%$ para $46 \%$.

Nas demais questões da categoria envolvendo textualização, a $11^{a}$ e a $18^{a}$ são bastante semelhantes; as duas apresentam um gênero textual e solicitam que a criança identifique a função do texto.

A $11^{a}$ é a primeira das questões que envolvem leitura de pequenos textos; em ambas, as crianças devem ler o texto e também as alternativas. Ao solicitar a identificação da finalidade do texto, as questões remetem aos gêneros textuais (tema bastante explorado nas orientações do MEC) ${ }^{12}$ e as discussões provenientes das teorias de letramento. Além da decodificação (domínio do sistema alfabético, imprescindível para a compreensão leitora), a criança

12 Rever o Quadro 3; outras orientações são encontradas durante o capítulo: "Para contribuir com o desenvolvimento da capacidade dos alunos de ler com compreensão, é importante que o professor ou a professora proporcione a familiaridade com gêneros textuais diversos [...], lendo para eles em voz alta ou pedindo-lhes leitura autônoma. Além disso, é desejável abordar as características gerais destes gêneros (do que eles costumam tratar, como costumam se organizar, que recursos linguísticos costumam usar, para que servem)." (BRASIL, 2007, p.44). 
deveria estar familiarizada com esses gêneros textuais, em convergência com evento de letramento ${ }^{13}$ em potencial - se considerada a possibilidade de uso real desses textos em situações interacionais efetivas -, deveria fazer parte de sua dinâmica familiar e/ou escolar. Embora o convite e o bilhete sejam bastante comuns, inclusive na escola, será que todas as crianças realmente os conhecem, na forma que lhes foi apresentada? Essas reflexões acerca da dimensão social da leitura, sozinhas, justificariam o baixo desempenho (63\% e 49\% de acertos, respectivamente) das crianças nessas questões? Podemos continuar a reflexão com outro dado interessante: na turma na qual a professora leu a questão inteira, a porcentagem de acertos foi maior (100\% e 74\%) o que, de certa forma, enfraquece o argumento da não familiaridade com o gênero e com o evento de letramento, e leva-nos a pensar que a dificuldade apresentada pelas crianças está mais focada na dimensão linguística, mais pontualmente no domínio do código alfabético ${ }^{14}$, habilidade requerida na compreensão leitora (o que corrobora as inferências de Megherbi (2009), sobre a distinção entre compreensão da linguagem ouvida e da linguagem lida).

Pensando agora somente nas respostas erradas, na $17^{a}$ questão, $71 \%$ das crianças assinalaram a alternativa "Convidar para jogar bola"; no texto há uma imagem relativa a aniversário, com um boneco usando chapeuzinho de festa e segurando um balão de ar. Aparentemente, não há relação evidente entre "Convidar para um aniversário" e "Convidar para jogar bola", a não ser o mesmo verbo, que inicia as alternativas. Não parece ter sido essa a dificuldade das crianças, pois a opção correta aparece antes da opção "jogar bola"; assim, se essas crianças tivessem respondido à questão apenas com a primeira palavra da alternativa, pareceria mais lógico assinalar a primeira alternativa. Também foi uma das questões que apresentaram maior porcentagem de não respostas; nas turmas em que as crianças deveriam ler sozinhas, $26 \%$ delas deixaram a questão em branco; na turma na qual a professora leu, todas as crianças responderam à questão. Na questão 18, a porcentagem de acertos também ficou abaixo da metade (49\%), com aumento significativo na turma em que houve a leitura do texto (74\%), o que denotaria, novamente, o não domínio do código escrito. As respostas equivocadas variaram em torno das três alternativas, com $43 \%$ dos alunos assinalando a alternativa "Contar uma piada", 39\% optando por "Fazer um convite" e apenas 18\% assinalando "Pedir um material". Interessante que, na turma em que a professora leu o texto e o enunciado, 100\% das crianças que erraram a questão assinalaram a última alternativa.

13 Eventos de letramento entendidos como situações comunicativas em que a escrita (ou a fala ancorada na escrita) têm papel prevalecente, ou seja, situações que envolvem letramento (BARTON, 1994).

14 Compreendemos que as crianças estão num processo de alfabetização e não estamos exigindo o completo domínio do sistema alfabético, mas o entendemos como necessário para a correta resolução da questão. 
Pensando somente no desempenho da turma que teve as questões lidas pelas professoras, observamos uma "queda" nos acertos de 100\% para 74\% nessas duas questões, aparentemente, de mesmo conteúdo. Novamente, as discussões acerca do letramento podem nos embasar nas discussões sobre essa "queda" no desempenho. Será que a prática de deixar recados escritos é familiar a essas crianças? Ou, com base em Lahire (2008): essas práticas de escrita fazem parte das formas familiares de cultura escrita em se tratando dessas crianças? A familiaridade com tais práticas como ferramentas cotidianas por meio das quais a criança recebe o afeto dos pais pode dar às práticas de escrita uma identidade social positiva e conduzir a criança ao "sucesso" escolar (ou, inversamente, práticas negativas, levando ao "insucesso"). Vemos, mais uma vez, a importância e a interdependência da dimensão sociocultural nas dimensões linguística e cognitiva da leitura.

Outras duas questões (questão 16 e questão 20) envolvem leitura de portadores de texto e apresentam dois gêneros de ampla circulação em diferentes estratos sociais, um cartaz e uma capa de revista, que devem ser lidos de maneira autônoma pelas crianças.

A $16^{a}$ questão apresenta um cartaz sobre campanha de vacinação e solicita a identificação do assunto do cartaz. Menos da metade das crianças (46\%) responderam corretamente a essa questão; mesmo na turma em que a professora leu a questão inteira, a porcentagem de acertos não foi alta (78\%), embora tenha sido superior às demais. As respostas equivocadas também são variadas, mas a alternativa "O jogo de futebol está no segundo tempo" foi assinalada por quase metade das crianças (46\%). Observamos que, no cartaz sobre a campanha, aparece a expressão " 2 ' tempo" como título, inclusive em cor (tom de cinza) diferente. Será que foi essa a relação estabelecida pelas crianças? Outra reflexão, envolvendo os conceitos de práticas e eventos de letramento (BARTON, 1994), faz-se necessária aqui. Sabe-se que, no Brasil, as campanhas de vacinação atingem excelentes porcentagens de adesão; ${ }^{15}$ dessa forma, muitas (para não dizer todas) as crianças vão ao posto de saúde com relativa frequência e são expostas aos comerciais sobre essas campanhas, porém não basta que elas sejam simplesmente expostas aos muitos gêneros textuais para que aprendam sobre eles; não basta que elas vejam, incidentalmente, os cartazes ou o comercial de televisão. Em outras palavras, não basta que haja usos da escrita, é necessário que tais usos sejam parte de práticas de letramento e se materializem em eventos nos quais a criança seja sujeito.

A segunda (questão 20) apresenta a capa de uma revista de jogos e passatempos da Turma da Mônica e solicita à criança que assinale a alternativa que traz o conteúdo da revista; as alternativas também deveriam ser lidas pelas

15 A segunda etapa da vacinação contra a Paralisia Infantil (campanha abordada no cartaz), em 2009, teve 96,10\% de cobertura vacinal em crianças de 0 a 4 anos de idade, segundo o Ministério da Saúde (BRASIL, 2009e). 
crianças. As turmas apresentaram uma média de acertos de 57\%. Novamente, a hipótese de não acesso ao código torna-se visível, pois, na turma na qual a professora leu as alternativas, os acertos chegaram a 100\%. Há, entre as opções, dois distratores que foram assinalados pelas crianças que erraram a questão: "Histórias e aventuras", que foi a opção escolhida por 45\% das crianças e "Contos", escolhida por 39\% das crianças. Parece-nos uma escolha plausível, pois é bastante comum observarmos gibis e revistinhas da Turma da Mônica que realmente contem histórias, aventuras e contos; porém está claramente escrito na capa da revista em questão "JOGOS E PASSATEMPOS". Supõe-se também que esse tipo de gibi circule com muito mais frequência entre as crianças, pois, tanto na biblioteca da escola quanto nas próprias salas de aula, esse material de leitura é bastante comum. Parece fato que essas crianças responderam à questão levando em conta informações de itens não verbais do texto, prevalecendo o reconhecimento de imagens em desfavor do conteúdo verbal escrito; assim, uma resposta baseada somente na identificação do portador de texto (capa de revista) sem a leitura das informações contidas na capa facilmente levaria a interpretações equivocadas. Novamente, nessa questão, chama a atenção o número de questões em branco, chegando a 17\% (e nenhuma na turma em que a professora leu a questão inteira).

Outras três questões (questões 21, 22 e 23) apresentam pequenas narrativas (de 8 a 10 linhas), envolvendo animais como personagens principais; as três são apresentadas da mesma forma, dentro de um quadro cinza, com a mesma fonte. Uma delas apresenta uma ilustração, e uma outra traz também um diálogo.

Nas três questões, a criança deve, além de realizar a leitura do texto, ler de forma autônoma tanto o enunciado quanto as alternativas, ou seja, não há interferência da professora. Nas três questões, a criança foi solicitada a localizar informações no texto; aliás, todas as respostas encontram-se na primeira linha da narrativa. O primeiro texto é uma fábula, chamada "O leão e o ratinho", e a pergunta relacionada a esse texto é "Quem dormia debaixo de uma árvore?". Para essa resposta, a criança deveria localizar, na primeira linha do texto, a informação. O segundo texto envolve uma vaca chamada Moqueca, que se apaixona e tem um bezerrinho; o texto finaliza com uma interrogação: "Qual será o mistério da vaca Moqueca?". Depois, a questão é "Nesse texto, Moqueca é", desconsiderando totalmente a questão apresentada pelo próprio texto. Além disso, no próprio texto há o desenho de uma vaca, o que parece não ter sido muito utilizado como apoio para a resposta da questão. O próximo texto tem uma girafa como personagem central e a pergunta é "Essa história acontece"; a criança deveria localizar as pistas no texto, pistas estas presentes na primeira linha da historinha.

Podemos inferir aqui que a leitura está sendo tomada como capacidade de localizar informações, o que está profundamente associado com a capacidade de decodificação. A porcentagem de acertos (53\%, 40\% e 37\%) dessas três questões 
em sequência pode denotar, também, o próprio cansaço ou eventual desinteresse das crianças. A crescente porcentagem de questões em branco (18\%, 27\% e $33 \%$, respectivamente) também poderiam ser um indício dessa hipótese, porém novamente os dados da turma na qual a professora realizou a leitura em voz alta (100\% de acertos nas questões 21 e 22 e 87\% na 23a) parece não contemplar essa hipótese e podem apontar em outras direções, confirmando as hipóteses de dificuldades de apropriação e interpretação da leitura e das articulações ente as estratégias de leitura.

Outro texto apresentado (Questão 24), considerado "comum" nas escolas, é o texto informativo, tipo de texto bastante frequente nos livros didáticos e nas revistas destinadas às crianças em idade escolar. O título do texto é "O que as plantas carnívoras fazem?" e, no decorrer do texto (de seis linhas), conta a informação de que as plantas carnívoras caçam insetos, porque e como elas fazem isso.

As crianças deveriam apontar o assunto do texto, o que deveria ser feito a partir da localização de informações em diversos pontos do texto e do estabelecimento de relações entre essas informações. Foi a questão com a menor porcentagem de acertos, tanto nas turmas em que as crianças deveriam ler o texto sozinhas quanto na turma que teve o texto lido pela professora (33\% e 74\%, respectivamente); houve uma porcentagem alta (23\%) de questões em branco e 66\% das respostas erradas apontaram a primeira alternativa como correta. Além disso, a questão envolve também a elaboração de conceitos científicos, com maior grau de abstração e menor concretude; esses conceitos apresentam maior dificuldade para crianças nesta idade do que as narrativas apresentadas nas questões anteriores. A apropriação conceitual começa e tem vinculação ao processo de aquisição de linguagem, mas os conceitos científicos ${ }^{16}$ têm modos de apropriação distintos dos conceitos espontâneos; enquanto os conceitos espontâneos são saturados de concretude e desenvolvem-se em direção aos processos de abstração, generalização e arbitrariedade, os conceitos científicos desenvolvem-se em direção contrária: da abstração à concretude (VIGOTSKI, 2001). Essa dimensão cognitiva da leitura pode, aliada às discussões anteriores sobre os aspectos linguísticos da leitura, justificar a maior dificuldade apresentada pelas crianças nesta questão. Acrescentamos ainda que esta é a última questão da Provinha; então, o próprio cansaço e/ou desinteresse das crianças deve ser levado em consideração.

Uma última questão analisada (mas não a última apresentada para a criança, na verdade, a $19^{a}$ ) apresenta um texto e solicita que o aluno infira significados a partir da leitura do texto. O texto é uma historieta curta, do tipo anedota,

16 Conceitos científicos são conceitos sistematizados, não diretamente acessíveis à observação ou ação imediata das crianças, adquiridos nas interações escolarizadas. (VIGOTSKI, 2001). 
envolvendo um diálogo, e a questão envolve as razões do comportamento do personagem, não explícitas no texto.

Foi uma das questões que apresentou a menor porcentagem de acertos (39\%); novamente, a turma que teve as questões e as alternativas lidas pela professora foi exceção, atingindo 96\% de acertos. Quanto às respostas equivocadas, todas as alternativas foram assinaladas, porém $50 \%$ delas referem-se à primeira alternativa apresentada. Esta questão também apresentou uma porcentagem elevada de respostas em branco (26\%), fato não observado na turma na qual a professora foi a leitora.

Assim, quando comparamos o desempenho das crianças em relação às questões focadas no código e aquelas envolvendo textualização, observamos uma relativa dificuldade nestas últimas. Se é preconizado ao professor que alfabetize a partir dos textos e não a partir de atividades isoladas, por que os alunos tiveram um bom desempenho nas questões que avaliam habilidades isoladas e não mantiveram esse desempenho quando apareceu o texto? Se os documentos municipais norteiam o trabalho de alfabetização a partir do texto (dimensão sociocultural da leitura), como explicar esta aparente contradição? Uma das possíveis explicações seria o fato das teorias adotadas pelos documentos oficiais não terem sido realmente consolidadas pelas práticas escolares e essas ainda seriam baseadas em atividades focadas no código. Ao mesmo tempo, o desempenho das crianças nas atividades baseadas no código é bastante heterogêneo, o que indicaria que as orientações dadas através do Pró-Letramento (BRASIL, 2007) também não estão totalmente consolidadas, principalmente aquelas relacionadas à reflexão metalinguística e à consciência fonológica (aliteração). Essas duas inferências concluiriam que as atividades cotidianas em sala de aula não estão privilegiando as três dimensões da leitura (sociocultural, linguística e cognitiva) de forma paralela, equivalente e efetiva.

\section{Considerações finais}

Compreendemos a importância de uma avaliação nacional que ajude a pensar e refletir sobre os processos de alfabetização e a prática pedagógica desenvolvida em torno da apropriação da língua escrita, mas, também, conhecemos os "efeitos colaterais" da adoção de propostas padronizadas, principalmente quando discutimos esse "padrão" à luz das teorias do letramento. Se pensarmos que o letramento ideológico considera a leitura e a escrita como práticas sociais e não como atividades com fins em si mesmas e que a Provinha Brasil é um instrumento padronizado que busca atingir igualmente todas as crianças da grande diversidade de escolas do país, já observamos uma divergência de posturas. 
Ao mesmo tempo, sabemos que a Provinha busca avaliar algumas habilidades necessárias e fundamentais à apropriação da leitura e da escrita, independentemente do contexto em que a criança se insere, o que a resguarda parcialmente da crítica feita acima. Afinal de contas, as especificidades da alfabetização - aprendizagem da técnica, domínio do código convencional da leitura e da escrita e das relações fonema/grafema, segundo Soares (2003) - devem ser apropriadas pelas crianças; voltamos a trazer as discussões do letramento. Como as especificidades da alfabetização serão apropriadas pelas crianças? A Provinha Brasil, ao avaliar as habilidades que as crianças já adquiriram, busca nortear o trabalho pedagógico a ser desenvolvido. A nosso ver, esse trabalho deve ser sim pautado nessas habilidades e também no seu uso social - modelo ideológico de letramento (STREET, 1984).-, posição já preconizada pelo PróLetramento (BRASIL, 2007, p.13):

O desafio que se coloca para os primeiros anos da Educação Fundamental é o de conciliar esses dois processos, assegurando aos alunos a apropriação do sistema alfabético-ortográfico e condições possibilitadoras do uso da língua nas práticas sociais de leitura e escrita.

Finalmente, retomando a primeira posição teórica defendida neste artigo, que a leitura deva ser entendida a partir das dimensões sociocultural, linguística e cognitiva (CERUTTI-RIZZATTI, 2009a), acreditamos que a Provinha Brasil em si, como um instrumento isolado contemple claramente as dimensões linguística e cognitiva, mas não consiga contemplar a dimensão sociocultural da leitura, porém essa dimensão seria facilmente considerada se os resultados apresentados pelas crianças forem discutidos a partir da microcultura escolar na qual ela foi realizada, buscando depreender não somente o erro/acerto, mas todo o processo avaliativo, refletindo sobre as hipóteses elaboradas pelas crianças ao responder o teste, tanto dos alunos individualizados quanto das turmas e da escola, abarcando, assim as três dimensões da leitura.

CRISTOFOLINI, C. Thinking through Provinha Brasil from the sociocultural, linguistic, and cognitive dimensions of reading. Alfa, v.56, n.1, p.217-247, 2012.

- ABSTRACT: The aim of this study is to analyze the extent to which reading, in its sociocultural, linguistic, and cognitive dimensions (CERUTTI-RIZZATTI, 2009), was taken into account in the first 2009 edition of the literacy standardized national assessment test, Provinha Brazil. To accomplish this goal, it draws on both the documents that guide the pedagogical actionboth national (BRASIL, 2007) and municipal (SÃO JOSÉ, 2000, 2007) - specified in the Guide Manuals included in the Provinha kit and the results of this assessment for five 2nd-year classes of a municipal school in Grande Florianópolis. The Provinha questions were classified into two major groups (decoding skills and textualization) and discussed individually, merging theoretical discussions on literacy with the results achieved by the students. The conclusion 
stresses that Provinha Brasil is biased towards the linguistic and cognitive dimensions of reading to the detriment of its sociocultural dimension.

- KEYWORDS: Reading. Literacy. Provinha Brasil.

\section{REFERÊNCIAS}

ALVAREZ, A. M. A. Perfil de habilidades fonológicas. São Paulo:Via Lettera, 1998.

BARTON, D. Literacy: an introduction to the ecology of written language. Oxford: Blackwell, 1994.

BRASIL. Ministério da Educação. Instituto Nacional de Estudos e Pesquisas Educacionais Anísio Teixeira. Provinha Brasil: orientações gerais: teste 1: primeiro semestre. Brasília, 2009a.

Ministério da Educação. Instituto Nacional de Estudos e Pesquisas Educacionais Anísio Teixeira. Provinha Brasil: passo a passo: teste 1: primeiro semestre. Brasília, 2009b.

Ministério da Educação. Instituto Nacional de Estudos e Pesquisas Educacionais Anísio Teixeira. Provinha Brasil: guia do professor(a) aplicador(a): teste 1: primeiro semestre. Brasília, 2009c.

Ministério da Educação. Instituto Nacional de Estudos e Pesquisas Educacionais Anísio Teixeira. Provinha Brasil: guia de correção e interpretação dos resultados: teste 1: primeiro semestre. Brasília, 2009d.

. Ministério da Saúde. Sistema nacional de informação do programa nacional de imunizações. Datasus. Campanha nacional de vacinação contra a pólio: $2^{a}$ etapa. 19 set. 2009e. Disponível em: <http://pni.datasus.gov.br>. Acesso em: 20 out. 2009.

Ministério da Educação. Secretaria de Educação Básica. Pró-letramento: alfabetização e linguagem. Programa de formação continuada de professores dos anos/séries iniciais do ensino fundamental. Brasília, 2007.

CARVALHO, I. A. M.; ALVAREZ, R. M. A. Aquisição da linguagem escrita: aspectos da consciência fonológica. Fono Atual, São Paulo, v.4, n.11, p.28-31, mar. 2000.

CARVALHO, R.; ANSON, V. R. Livro de alfabetização. São Paulo: FTD, 2005. (Coleção A Grande Aventura: Língua Portuguesa).

CERUTTI-RIZZATTI, M. E. Sociocognição e linguagem escrita: uma discussão sobre leitura na escola. São José, SC, jul. 2009a. Palestra proferida na Semana da Educação de São José. 
. Sociocognição e linguagem escrita:uma discussão sobre implicações das fronteiras do conceito de letramento. Florianópolis, 2009b. No prelo.

KLEIMAN, Â. Modelos de alfabetização e as práticas de alfabetização na escola. In: (Org.). Os significados do letramento. Uma nova perspectiva sobre a prática social da escrita. São Paulo: Mercado das Letras, 1995. p.15-61.

LAHIRE, B. Sucesso escolar nos meios populares: as razões do improvável. São Paulo: Ática, 2008.

MALUF, M. R.; BARRERA, S. D. Consciência fonológica e linguagem escrita em pré-escolares. Psicologia:Reflexão e Crítica, Porto Alegre, v.10, n.1, p.125-145, 1997.

MEGHERBI, H. Functional acquisition of linguistic devices and reading comprehension difficulties. UFSC, Florianópolis, nov. 2009. Palestra.

SCLIAR-CABRAL, L. Princípios do sistema alfabético do português do Brasil. São Paulo: Contexto, 2003.

SÃO JOSÉ. Rede Municipal de Ensino. Ensino Fundamental de 9 anos: organização curricular na perspectiva do direito à infância e à juventude. Caderno Pedagógico, São José, 2008. p.37-57.

. Secretaria Municipal de educação. Prefeitura Municipal de São José. Alfabetização. 4.ed. São José, 2007.

Secretaria Municipal de educação. Prefeitura Municipal de São José. Proposta Curricular de São José. São José, 2000.

SILVA, T. T. da. Documento de identidade: uma introdução às teorias do currículo. 2.ed. Belo Horizonte: Autêntica, 2002.

SOARES, M. A reinvenção da alfabetização. Cultiva, 2003. Disponível em:

$<$ http://www.cultiva.org.br/textos/reinvecao_da_alfabetizacao_magda.doc $>$. Acesso em: 02 dez. 2006.

STREET, B. V. Abordagens alternativas ao letramento e ao desenvolvimento. [S.l], out. 2003. Teleconferência Unesco Brasil sobre letramento e diversidade. Disponível em: <http://www.unisesi.org.br/portal/arquivos/biblioteca/12>. Acesso em: 20 out. 2009.

1984.

. Literacy in theory and practice. Cambridge: Cambridge University Press,

VIGOTSKI, L. S. O estudo do desenvolvimento dos conceitos científicos. In:

A construção do pensamento e da linguagem. São Paulo: Martins Fontes, 2001. p.242-394. 
ZORZI, J. L. Consciência fonológica e fases de desenvolvimento do letramento infantil. In: SIMPÓSIO NACIONAL SOBRE DISTÚRBIOS DE APRENDIZAGEM, 6., 2002, São Paulo. Anais... São Paulo: Futuro Congressos e Eventos, 2002. p.131-140.

Recebido em setembro de 2010.

Aprovado em novembro de 2010. 